Promoting ethanol in rural Kansas: local framings and cultural politics

Theresa Selfa+, Albert Iaroi and Morey Burnham

+ corresponding author

Theresa Selfa

Environmental Studies

SUNY ESF

Syracuse, NY 13210

tselfa@esf.edu

Albert Iaroi

Kansas State University

Department of Sociology

Manhattan, KS 66503

Morey Burnham

Environmental Studies

SUNY ESF

Syracuse, NY 13210 


\section{Promoting ethanol in rural Kansas: local framings and cultural politics}

"[Ethanol] is good for our rural economies, good for our environment and good for our state and nation, [former Kansas Governor] Sebelius said.” (Staatz, 2007)

"The promise of the bioeconomy is in part realized through the creation of green collar jobs - jobs involved with the production of bioproducts and biofuels - for Kansans, especially those in rural areas."

Former Kansas Secretary of Agriculture Adrian Polansky, 2008

\section{Introduction}

The ethanol industry in the U.S. emerged in the mid-2000s, promoted to mitigate the effects of climate change, increase energy independence, and bring economic development to declining rural areas. The agriculturally-dominated Midwestern U.S., where the consolidation and industrialization of low-value commodity agriculture had contributed to declining rural economies during the 1980s and 1990s, was primed for the new opportunities that the ethanol industry presented (Johnson and Rathge, 2005). While evidence that the ethanol industry would actually create a substantial number of jobs and economic development in rural areas was limited, many state and local governments forged ahead with promoting the rural economic development potential of the industry (Lehrer, 2010; Bain, 2011).

In Kansas, the state with the third highest number of acres in agriculture in the U.S., state and local politicians, investors, and other stakeholders promoted the ethanol industry as the 'best fit' for the state's grain farmers, rural communities, and the economic development of the state. Key political and economic stakeholders emphasized both local economic and national energy independence benefits of ethanol in order to 
facilitate the establishment of biorefineries in rural communities. To bolster support, promoters of biofuels development stressed the importance of agriculture to the state's economy and identity, despite several decades of decline in agriculturally related jobs, rural depopulation, and a diminishing natural resource base.

In this paper, we explore how local promoters framed the development of the ethanol industry by attaching it to locally salient discourses related to the environment, rural economic development, national security and energy independence, and the cultural importance of agricultural production. This builds on the work of other scholars (Bell and York 2010; Habermas, 1975; Sherman, 2009) who have shown how powerful actors pursue legitimation by using cultural manipulation to encourage individuals and communities to identify with industries that are not necessarily in their economic interests. Following Dryzek (1997), we understand discourse as a shared way of understanding the world that allows actors to put disparate information together to make coherent narratives. Key actors or stakeholders exercise power by imposing a particular frame or discourse on to a discussion (Hajer and Versteeg, 2005). We examine the discourse and cultural politics surrounding biofuels in western Kansas through an analysis of the promotion of ethanol production in one state level and four regional newspapers. In addition, we draw on key informant interviews in rural communities in western Kansas conducted to understand perceptions of the promises and impacts of the ethanol industry at the local level. We argue that by linking ethanol production to localized economic and environmental benefits, and to national security and energy independence agendas, the discourse promoting biofuels development in the local media discounted any discussion 
of climate impacts and reframed natural resource issues to justify local claims for continued water mining for agricultural production.

In the next section, we outline recent rural studies literature that examines the cultural politics of rural economic and environmental change as well as literature that interrogates the discourse and framings of bioenergy development. Both literatures inform our analysis of how the emergence of the ethanol industry in rural Kansas is promoted in regional media. Following the literature review, we provide a brief historical background on the factors facilitating the development of the ethanol industry in western Kansas. A description of the methods and data used in this study is followed by our findings and a discussion of the implications of our case study.

\section{Literature review}

Recent rural studies literature in the U.S. explores the cultural politics that surround economic change in rural regions, a departure from much of the previous rural community studies literature. In the 1980s, U.S. rural sociology literature focused on the impacts of the farm crisis on rural communities and families (Brooks et al., 1986; Bultena et al., 1986; Dudley, 2002;) and on community level vulnerabilities associated with rural resource dependent and extractive economies (Brown et al., 1989; Freudenburg, 1992; Freudenburg and Frickel, 1994). Rural studies in the 1990s examined how economic restructuring and globalization were creating uneven development, resulting in outmigration and economic decline for many rural communities (Flora et al., 1992; Lyson and Falk, 1993; Lobao, 1996). The recognition that cultural factors play an important role in shaping communities led to a wave of research that demonstrates the importance of 
identity, values, and symbols to understanding trajectories of rural change (Buttel, 1996; Dupuis and Vandergeest, 1995).

Reflecting the 'cultural turn' in rural studies in the 2000s, this new scholarship gives more attention to investigating the role of discourse and culture in the construction of rural identities and survival strategies in the face of declining economic opportunities (Cloke, 2006; Panelli, 2006). In her ethnographic study of a declining former logging town in northern California, Jennifer Sherman (2009) focuses on how residents use moral discourses to cope with their situations. Moral discourses related to the importance of "family values" and "hard work" regulate behavior in this small rural community, and are a source of distinction and stratification among residents who are all equally poor and lacking in opportunities. She demonstrates that survival strategies in declining rural communities are often chosen because they are socially and culturally acceptable rather than economically optimal.

Recent work by Bell and York (2011) and Scott (2010) examine why rural mining communities support destructive mining practices even though they realize that mining is eroding their livelihoods, destroying the environment, and undermining their landscape and sense of place. Bell and York (2011) show how local elites in the coal industry in West Virginia successfully appropriate cultural icons to convince residents of the importance of the coal industry to community economic well-being and identity, despite declining job availability and benefits from the industry. Additionally, they highlight the role that ideology and legitimation play in maintaining elite rule through persuasively attaching community economic identity to the extractive industry. 
Scott (2010) also examines why rural residents tolerate mountaintop removal mining (MTR) and how the destructive practice is normalized in West Virginia. She argues that place, race, and gender identities interact to provide local support for the practice of MTR. Drawing from the work of Kuletz (1998) and Fox (1999), Scott shows how the coalfields in Appalachia are treated as a national "environmental sacrifice zone," a place that is destroyed and "written off" for the higher national purpose of extracting coal for electricity, a move made possible by the region's economic and cultural marginalization from mainstream American culture and centers of power.

In a case study in rural Kansas, Solis (2005) illustrates how cultural and economic heritage arguments are deployed as a defense against the transfer of water rights from rural to urban uses. By appealing to their history as a farming community reliant on access to irrigation water, community members galvanize opposition to the water transfer by framing it as a challenge to their cultural identity. Similar to the case of MTR described by Scott (2010), stakeholders in this Kansas community naturalize water as being "locally owned, place-based and an inalienable resource" for the farming community, despite the long-term trend toward declines in farming and water availability in the region (Solis, 2005:62). In sum, this recent rural studies literature points to the importance of understanding the role that culture and discourse play in justifying activities that may undermine the economy and natural resource base of rural communities.

Our analysis also builds on emerging studies of the discourse surrounding biofuels. Arguing that the diffusion of renewable energy technologies is more than just an economic and technical process, Skjølsvold (2012) studies how bioenergy is covered 
and ascribed meaning in the news media in Norway and Sweden, finding Swedish coverage to be optimistic and Norwegian coverage to be ambivalent. He argues that the difference is the result of each country's histories, local practices of power generation, and their differing approaches to climate change mitigation. Drawing on interviews and media analysis, Eaton et al. (2014) investigate how community members and the local media in four northern Michigan communities where bioenergy projects were proposed frame the national bioenergy "imaginaries" that fuel local bioenergy projects. They demonstrate how national bioenergy energy imaginaries are reinterpreted differently by different local actors, and argue that people draw on their "lived experiences, remembered histories, and community and technical discourse" to align themselves with frames that either support or oppose local bioenergy development (Eaton et al, 2014: 251). Sengers et al. (2010) also draw on media analysis and interviews with practitioners to examine how biofuels discourse shifted in the 2000s in Norway from largely laudatory to a resistance framing, and how this shift affected biofuels practice.

Wright and Reid (2011) identify and analyze the diagnostic frames used by the national media in The New York Times to portray the U.S. biofuels' movement in order to increase investment and development of the industry. They show how three frames-economic development, environment, and national security--are frequently packaged together by the media to advocate for biofuels development. Employed most frequently in the national discourse, the economic development frame primarily communicated the "robustness of the emerging biofuels market" in order to portray biofuels as a safe investment and highlighted vaguely defined benefits for rural communities and farmers (Wright and Reid, 2011:1395). The environmental frame legitimized biofuels 
development through claims that biofuels could reduce fossil fuel use and mitigate carbon emissions, thus helping to slow climate change. The national security frame was the least often employed, and was characterized by statements that drew attention to the U.S. overreliance on Middle Eastern oil. Lehrer (2010) examines variations of these same three frames at the national level, demonstrating how these frames emerged at a particular political juncture and contributed to the inclusion of biofuels in the 2008 U.S. Farm Bill and its passage. Lehrer also shows that that the environmental frame at the national level includes a broader conservation emphasis that expands the role of biofuels beyond addressing climate change through carbon emissions reductions, to include claims that feedstocks for bioenergy could help to protect soil and water quality and fish and wildlife habitat. However, because Lehrer (2010) and Wright and Reed (2011) only analyze the national media, their studies do not adequately address framings of the local economic or agricultural interests and context driving biofuels development, which is the focus of our study.

In this study we employ a framing analysis method (Atheide, 1996; Entman, 1993; Tankard, 2003) to illuminate the discourse, or the themes and messages, that biofuels proponents - representatives of local government, the ethanol industry, farmers, diverse lobby groups, and politicians - utilize to advocate for biofuels development in the regional media. Frame analytic approaches define frames as socially constructed and negotiated schemata that guide our interpretations and representations of reality (Goffman, 1974; Wright and Reid, 2011). Frames are used by policy makers, the media, and other social actors to organize fundamental ideas and define controversial issues, often in such a way that they resonate with existing core values and assumptions. Frames 
simplify complex issues by giving some aspects of an issue greater emphasis, while backgrounding others, allowing readers to "rapidly identify why an issue matters, who might be responsible, and what should be done" (Nisbet and Mooney, 2007: 56).

Drawing on these literatures, this paper examines the discursive frames that are harnessed by local stakeholders in Kansas to support the development of the ethanol industry and justify its importance to both local communities and the nation. By employing a frame analysis of regional newspapers, supplemented with key informant interviews in these communities, we explore how local proponents of biofuels development in western Kansas attach biofuels to locally salient issues to advocate for industry development, at the same time sidelining climate implications and justifying continued water extraction for agriculture and ethanol production. The next section details the background and history of agricultural development in western Kansas that set the stage for the emergence of the ethanol industry.

\section{The road to biofuels production: agriculture and the economy of Kansas}

Agriculture and food processing, as well as oil and gas extraction, have historically been the pillars of the Kansas economy, particularly in western Kansas. While manufacturing and services currently produce a greater share of state income, agriculture is still the dominant land use in the state and for many rural counties in western Kansas, agriculture is the primary industry. Agriculture and farming also continue to be symbolically important to the cultural identity of Kansas, tellingly known as the "Sunflower State" (Solis, 2005).

In the mid-1800s, settlers were lured to semi-arid western Kansas by the promise of bountiful harvests facilitated by a cycle of above average precipitation (Sherow, 1990). 
Farmers in western Kansas started irrigating their newly broken lands shortly after statehood in 1861 by channeling surface water through their fields. The irrigation of millions of acres of cropland in western Kansas accelerated after World War II when deep-well technology made water sources from alluvial aquifers along the rivers accessible. Further, deep-well turbine pumps enabled farmers to tap the Ogallala Aquifer, which underlies approximately 33,500 square miles of farmland in western Kansas (Sophocleous 2010).

The expansion of center-pivot sprinkler systems in the 1970s allowed farmers to irrigate large circles of dry land and obtain good crop yields. Center pivot irrigation systems enabled the transformation of what was marginal land into one of the most productive agricultural regions in the country, creating the abundant supply of feed grain that triggered the growth of commercial feedyards in western Kansas (Stull and Broadway, 2004).

Since the 1970's the percentage of the state's gross domestic product (GDP) from agriculture has decreased while the GDP from services and finance has become much more important. Between 1970 and 1975 agriculture represented over 10\% of the GDP of Kansas but declined to less than 3\% in the period between 2000 and 2005 (Hall 2010). During the same time period, the share of services in Kansas' gross domestic product increased from $12.5 \%$ to $20 \%$. (Ibid, 2010). Despite agriculture's declining contribution to the state's economy, agriculture remains the predominant land use in the state and the agricultural lobby retains considerable power. The emergence of the biofuels industry in the mid-2000s dovetailed with efforts to maintain agriculture's strong presence, especially in the western half of the state. 
In 1983, Kansas farmers harvested 1.10 million acres of corn. By 1996 this number had expanded to 2.48 million acres, and by 2006 acreage had grown to 3.3 million harvested acres of corn, with nearly half of it the grown in the western region of the state (USDA, NASS). The majority of corn acreage in western Kansas requires irrigation, and in in 2006, 92\% of corn acreage in Southwestern Kansas was irrigated (USDA NASS, 2007). In addition to irrigation, growing corn requires heavy fertilizer and pesticide inputs; research has documented that the extensive use of nitrogen fertilizer and pesticides is severely impacting water quality in the Midwest, and ultimately contributes to eutrophication in the Gulf of Mexico (NRC 2008).

The emergence of ethanol biorefineries anticipated a wave of economic growth that would revitalize rural communities across the Midwestern U.S. As early as the 1930s, grassroots efforts in the Midwest were launched to use surplus grain to produce fuel. However, these initiatives were strongly opposed by the petroleum industry and were eventually undermined by New Deal agricultural policies that curtailed grain production (Carolan, 2009; Lehrer, 2010; Wright and Reid, 2011). In contrast, in the mid2000s, state and local governments enacted policies designed to incentivize ethanol production facilities, and local governments in small rural communities invested considerable resources in local infrastructure with the expectation that the resultant economic growth and tax revenues would benefit the community (Author et al., 2011). Indeed, many rural communities competed with each other to attract such facilities (Bain, 2011), as reflected in local media statements that demonstrate the economic development expectations pinned on ethanol development by local communities: 
Promoting Ethanol in Rural Kansas: local framings and cultural politics

"Ethanol fever fires up heartland. [...] Investors are spending billions in rural communities, sparking a wild rush to secure land, an industry movement to alter environmental standards and a rash of fierce bidding by communities desperate for their own plant.” (Browning et al., 2007)

In June 2007, Kansas had eight existing ethanol plants, four under construction and 17 more were proposed; by 2011, there were 12 operating ethanol plants, none was proposed and one was idled due to bankruptcy (NEO, 2014), reflecting the downturn in enthusiasm for bioenergy expansion. Gateway Energy was the largest ethanol plant in Kansas when it opened in October 2007; it closed a few months later and went into bankruptcy in December 2008, citing the high price of corn (Kansas Energy Information Network, 2013). Numerous bankruptcies in the ethanol industry in the late 2000s were related to lower demand for gasoline, a widespread drought that increased the price of corn, and the purchase of corn at locked-in high prices by many ethanol producers, after which the price of corn dropped dramatically in late 2008 (McCracken, Resnick-Ault, and Etter, 2008). The Kansas ethanol plants employed between 30 and 50 workers, so although both the creation and loss of direct jobs in these plants were modest, interviews with city officials indicated concerns about the long-term costs associated with attracting and supporting the plants, including various tax incentives and infrastructure costs (Author et al 2011). During the period 2000-2010, most western Kansas rural counties continued to experience declines in population (11 and $12 \%$ for two case study counties) and the poverty rate in 2009 ranged from 6 to $24 \%$ for our case study counties, suggesting that 
the ethanol industry had not reversed depopulation nor dramatically improved the economic fortunes of these communities (US Census, 2010).

The expansion of ethanol production in Kansas in the mid-2000s was also challenged by its dependence on a declining supply of available water. Beginning in the 1970s, withdrawals from the Ogallala/High Plains aquifer for agricultural purposes exceeded the natural rate of recharge in some regions of the state, a trend that continues today, though at a slower pace (Golden and Peterson, 2006). In the mid-2000s, irrigation accounted for $87 \%$ of total water use in the region (Krider et al., 2006; Mintert et. al., 2006; Peterson et al., 2003). More recent analysis of water withdrawals for agriculture from the High Plains Aquifer shows that in the western Kansas region with the lowest mean annual precipitation (.4 to .5 meters), a substantial amount of groundwater (from 101 to 342 million cubic meters) is being used for crop irrigation, with much of the water being used for corn production (Steward et al. 2013:3477). To date, 30\% of the groundwater stored in the High Plains Aquifer of Kansas has been pumped, and if current irrigation trends continue, another 39 percent will be depleted in 50 years (Steward et al. 2013). Any expansion of the ethanol industry would likely exacerbate stresses on available water supply from the Ogallala/High Plains Aquifer, both for increased corn production and the conversion of biomass to fuel in biorefineries. While water use by biorefineries is relatively small in comparison to the water requirements of the crops used to produce ethanol, it can be locally significant. Studies have shown that a biorefinery that produces 100 million gallons of ethanol per year uses enough water to supply a town with a population 5,000 people over the same time period (NRC 2008). Given that current withdrawals are already well-above the recharge rate, this amounts to an 
unsustainable mining of the water resource. In contrast to ethanol refineries, the water needed to produce ethanol feedstock is quite large. Research has indicated that to grow the corn for one gallon of ethanol requires nearly 780 gallons of water, more than 200 times the amount used by a biorefinery to produce a gallon of ethanol (NRC 2008). Taken together, the amount of water used for corn production and the refinement process may potentially cause both local and regional water availability problems.

While Kansas state water policy calls for achieving an absolute reduction in water consumption from the Ogallala Aquifer and slowing aquifer-decline rates, our analysis below illustrates how political-economic forces lobby strongly to maintain and expand agriculture and related industries in western Kansas through continued water mining. Water use for agriculture and ethanol is framed as an entitlement that is necessary for community economic survival. In the next section we describe the methods and data used in this study.

\section{Data and Methods}

Three case study communities in western Kansas were chosen for analysis in this study: Liberal, Phillipsburg, and Russell (See Figure 1). These three communities were part of a larger study that examined the costs and benefits of ethanol production in six communities in Kansas and Iowa with ethanol plants (See Author, 2011). Each community was rural (or non-metropolitan) and was home to an ethanol plant. In addition to the presence of an ethanol plant, we purposively sampled communities to represent "maximum variation" in a number of variables, such as geographic features, i.e. water scarcity and/or availability, size of ethanol plant, communities with locally owned or 
absentee owned ethanol plants, and communities that were supportive and/or opposed to the ethanol plant (Creswell, 2013).

Primary data for this paper consist of 95 newspaper articles about ethanol development published in four regional newspapers and one state-level newspaper in Kansas between January 2005 and December 2009. Four search terms - ethanol, biofuels, renewable energy, and development - were used to identify news accounts related to biofuels development in two online databases ${ }^{1}$.

These terms were chosen because they are broad referents to biofuels development frequently used in news media coverage of the issue (e.g. Wright and Reid, 2011). Data for Russell and Phillipsburg were collected from two regional newspapers: The Hays Daily News (HDN) and The Salina Journal (TSJ). Articles from The Hutchinson News (THN) and The Garden City Telegraph (GCT) were searched for content about ethanol production in Liberal. The Topeka Capitol Journal (TCJ), published in Topeka, the capital city of Kansas, was searched for content on state-level decisions and opinions regarding ethanol production.

\footnotetext{
${ }^{1}$ The Hays Daily News and The Salina Journal articles analyzed for this study were obtained through NewsBank, an online database that provides access to current and archived content from more than 2,000 newspapers, newswires, transcripts, business journals, periodicals, and government documents. Relevant articles from The Garden City Telegram, and The Hutchinson News were collected through NewspaperArchive, an online database of digitized newspapers. Data from The Topeka Journal were collected directly from the newspapers' online archives.
} 


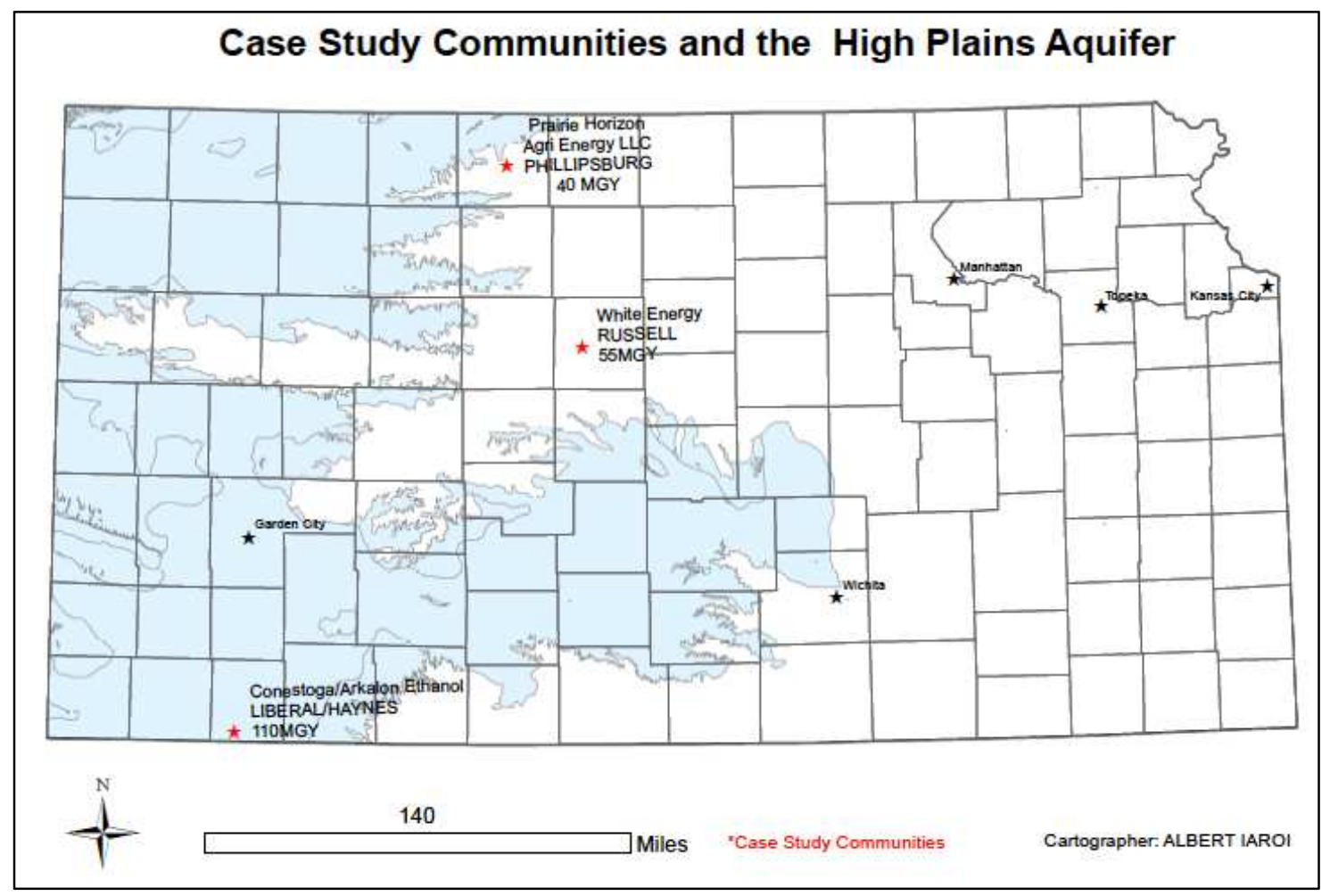

Fig.1. Map of Kansas and case study communities

The analyzed time period was chosen to include articles written in anticipation of ethanol plant construction in Kansas, the initial excitement after plants opened, the heightened regional scrutiny that biofuels development in western Kansas received due to a severe drought in 2006, and national and international debates about the environmental and food security impacts of biofuels. By the end of 2009, we found that biofuels development issues were sidelined in the regional media as other topics gained importance.

The articles were coded and analyzed followed the framing analysis methods employed by Altheide (1996), with a focus on identifying the types of claims made about biofuels development in the region and the actors making the claims. We created an extensive database of claims made about biofuels development in the articles. These 
claims were quite diverse, ranging from "it's a modern day gold rush", "the sound of money", "blessing for many farmers" and "hope for rural communities", to "is better for our environment”, "contributes to a cleaner environment and helps ease our energy dependence”, “improves our national security”, and "it's the future!" We narrowed these claims into three analytical frames: economic development, energy independence/national security, and environmental dimensions of biofuels development ${ }^{2}$. While the three frame categories we employ share similarities with the national level frames identified by Wright and Reid (2011), the logics and issues that underpin each frame are expressed differently in these rural communities in western Kansas, as discussed below.

The media content analysis was supplemented by data from key informant interviews in all three communities. These interviews were part of the larger study conducted between 2006-2010 (See Author, 2011). Over 30 individual interviews were completed with local government officials, community members, business leaders, utility managers, and management staff at ethanol plants in each community. In addition, focus group interviews were held with farmers, ethanol plant workers, community members, and local business owners. Interviews were transcribed verbatim and were analyzed to identify themes that describe how biofuels are framed by different local actors. In the next section we present our findings from the media content analysis, which is complemented by interview data.

\footnotetext{
2 To ensure the reliability of our analysis, two coders performed reliability checks on the findings reported here using a systematic sample of one quarter of the articles included in our data set. We refined our checks until we reached a high inter-coder agreement.
} 


\section{Results and discussion}

Over the studied time period, the economic development frame was consistently dominant (77), with the exception of 2006 when the number of articles containing an environmental frame was nearly equal to that promoting the economic development benefits of biofuels. The significant spike in articles employing an environmental frame in 2006 is likely related to the severe drought in western Kansas that ignited a debate about the viability of biofuels in a region with an agriculture-based economy already reliant on groundwater mining from the ever-diminishing Ogallala Aquifer. During 2005-9, the national security/energy independence (40) and environmental (48) frames were present in nearly the same number of articles in the western Kansas media.

In the following sections we discuss in more detail how cultural politics shaped the discursive frames used in the western Kansas media to advocate for biofuels development in locally contingent ways. For example, the energy independence frame as employed in western Kansas has strong national security and xenophobic overtones, reflecting the political conservatism of the region by playing off of fears of terrorist attacks on the United States by oil rich countries. While the Kansan economic frame shares similarities with the national economic frame as identified by Wright and Reid (2011) and Lehrer (2011), it is frequently expressed in terms of specific local community benefits, with biofuel refineries characterized as good "corporate citizens" for their financial support of local institutions. Finally, issues referenced by the environmental frame are determined by local politics and natural resource dependencies. In contrast to national environmental frames, there is essentially no discussion in the local media of the climate implications of biofuels or the benefits of biofuels for improving soil and water 
quality and protecting wildlife and fish habitat. Likewise, while environmental frames that challenged the environmental benefits of biofuels began to outnumber positive framings in the national media in 2008 (Wright and Reid, 2011), negative environmental framings were not present in our regional articles, as the discourse in Kansas remained nearly wholly supportive of the environmental benefits of biofuels. In the western Kansas media sources, natural resource concerns are minimized while natural resources issues (particularly water use) are naturalized so that they are positioned as inevitable and then reframed to cast a positive light on the ethanol industry. These themes are discussed in greater detail below.

5.1 The energy independence/national security frame: 'alternative fuel from the Midwest'

The energy independence/national security frame focuses on how locally produced ethanol from agriculture in Kansas will help reduce dependence on crude oil imports and increase national security. While this frame was identified as the least frequently used by national media (Wright and Reid, 2011), in rural Kansas it appeared nearly as often as the environmental frame. Wright and Reid argue that this framing of biofuels production resonates at the national level with "nativist proclivities that exalt localism as a counter to threats to global interdependence" (2011: 1394). The regional media in Kansas mirrors the national frame, but emphasizes the contribution of an agriculturally-derived alternative fuel source to national security. Similar to the national energy independence/national security frame, local politicians often highlighted the national security benefits of ethanol in relation to U.S. foreign policy and anti-terrorism efforts: 
"But it's also an opportunity for affordable fuels for consumers, he [Congressman Jerry Moran] said, and for better national security. [...] We are spending billions of dollars (for oil) outside the United States, and those dollars could very well be used in attacks against our country, against our economy and against our American citizens." (Kessinger, 2006a)

In this frame, energy independence is positioned as a national security issue, and ethanol production in western Kansas is championed for its contribution to national security.

"We, the citizens of Kansas and the United States, must start to become less reliant on foreign oil and look at products that don't use foreign oil for our automobiles, trucks, tractors and combines: ethanol and soy-diesel. [...] Filling your gasoline-powered car or truck with a 10 percent blend of ethanol will reduce our dependence on foreign oil by 10 percent." (Phelon, TCJ 0522 2004)

However, the regional newspapers go beyond the national frame and incorporate locally salient arguments to promote ethanol development through the voice of ethanol supporters that specifically appeal to the state's agricultural heritage. For example, former Kansas governor Kathleen Sebellius proudly champions the state's contribution to the country's national security while linking biofuels to Kansas's agricultural roots:

"America is looking for new sources of energy.[...] In Kansas, and in rural areas throughout the nation, we're finding those sources in the 
grains and grasses that have been grown on the land for generations, and in the wind that blows across the fields and prairies." (Kessinger, 2006b)

In the western Kansas media, ethanol is framed as a homegrown industry built on the investment and labor of Americans. The discourse suggests that if biofuels are the future for the United States, Kansas will be at the forefront of the transition.

Interview data also illustrate how local advocates frame biofuels development in the region as necessary for lessening the nation's dependence on the crude oil imported from the Persian Gulf region and other politically unfriendly countries. For example, one community member stated:

“Then you've got Saudi [Arabia], Mexico, Venezuela, Iraq, Iran, Nigeria who are your other suppliers. Almost all of them are against us, except maybe Mexico, oh and Canada - it's another big supplier. Except for Mexico and Canada, all of them are against us and for national security purposes, we need to be at sixty to seventy percent. If we have sixty to seventy percent of our supplied fuel available internally, then we're viable." (Phillipsburg interview \#3)

Likewise, an ethanol plant manager uses both xenophobic and environmental rhetoric to promote local ethanol production:

"As far as the bioenergy, the ethanol side of it, it amazes me the amount of money the American people are spending in buying oil overseas. The amount of wealth our country is losing is phenomenal; that's going to a foreign country when we have the capabilities of producing an energy form that is basically green-it's 
Promoting Ethanol in Rural Kansas: local framings and cultural politics

natural - and we happen to be sequestering our carbon, our CO2." (Liberal interview \#8)

Further, ethanol, as an alternative green fuel, is hailed as a way for western Kansas communities to profit substantially while supplying urban centers on both coasts with cheap domestically produced renewable fuel. Local and state-level politicians emphasize that through the production of home-grown fuels, these small farming communities are playing an important role in the march towards attaining national energy independence.

"The tiny town of about 3,350 has also become part of a new supply chain, where a small group of fuel distributors and ethanol barons stand to make a mint shipping the alternative fuel from the Midwest, where it is made, to major urban markets on both coasts.” (Burke, 2006)

While energy independence was identified as an important theme in the national narrative around biofuels (Lehrer, 2010; Wright and Reid, 2011), our analysis illustrates how these themes play out differently in rural Kansas. These small and politically conservative communities express pride in being able to contribute to the energy needs of coastal urban centers through the production of an agriculturally-derived alternative fuel source. They play up xenophobic rhetoric to show how the ethanol industry in rural Kansas will break dependence on oil from unfriendly foreign countries, protect the United States from terrorist attacks, and contribute to our national security interests. By combining patriotism and concerns about the national security implications of relying on foreign oil imports, as well reinforcing the importance of rural agricultural communities 
to the functioning of coastal urban centers, biofuels advocates attempt to galvanize support for the development of the ethanol industry in Kansas, driving its growth.

\subsection{The economic development frame: 'part of the community'}

Local promoters of biofuels development employed an economic development frame with several dimensions in the analyzed newspapers. Wright and Reid (2011) argue that the bioenergy economic development frame used in the national media focuses on "free market capitalism, in which the right to profit and unfettered competition are central" (2011: 1396). They highlight how the national media portrays biofuels development as a safe investment through which investors stand to gain huge profits, and as an industry that will bring a somewhat amorphous set of benefits to flagging rural communities. The economic development frame identified in Lehrer's (2010) study is similar, making broad claims about biofuel's benefits to rural economies. In contrast, in Kansas, where depopulation and economic decline have affected many rural communities, these economic benefits are depicted in locally significant and specific ways. Ethanol plants in western Kansas are portrayed as community benefactors and partners providing public finances and local jobs, while also revitalizing family farms and small rural communities. The analyzed articles suggest that ethanol plants are a "win-win" proposition for host communities, bringing an opportunity for locals to invest in this emerging, profitable business. The ethanol facilities are often depicted as good corporate citizens and good neighbors, and corporate donations to the local school district are always well-publicized: 
Promoting Ethanol in Rural Kansas: local framings and cultural politics

“U.S. Energy donated \$5,000 to help pay for fuel for field trips. The district didn't have money for field trips last year, and planned to limit them this year before the donation." (Sherard, 2005)

The economic benefits that ethanol facilities bring to rural communities are also linked to reversing decline, promoting the idea that the ethanol industry will help rescue rural Kansas from depopulation and economic misfortune:

"It's nice we have a business partner in the community. [...] It's a win-win situation. It helps us keep students here. With declining enrollment the more students we keep the better, [USD 407 Superintendent] Couch said.” (Sherard, 2005)

Proposals for locating an ethanol plant in the region are often highlighted in newspapers starting from the early stages of planning. One of the strongest and most frequently used arguments for building an ethanol plant is the creation of a significant number of well-paid direct and indirect jobs, as well as greater demand for local agricultural products:

“Nick Hatcher, president of Conestoga Energy Partners, LLC, which is developing the plant [near Liberal, Kansas], said the 55-million-gallonper-year dry mill ethanol plant would create more than 200 construction jobs and 2,200 sub-contracting jobs during the construction phase that would add $\$ 81$ million to the area economy. [...] Hatcher said when the plant is operational, it likely would employ 35 to 45 people full time and create an additional \$16 million for the area's economy.” (Wilson, 2006) 
Ethanol industry boosters emphasize the economic benefits expect to accrue for the whole region from the siting of a biorefinery, including increasing the local salary and tax base and local expenditures. The biofuels industry is touted for creating numerous jobs in the initial phases of refinery construction and for employing a substantial number of people in the refinery. The state level newspaper celebrates the potential revitalizing effect of biofuels development on rural communities:

“Water use isn't the only measure of an ethanol plant's potential effect. [...] According to impact analyses done of project plans in Ford and Seward counties, for instance, the two complexes would collectively generate \$32.4 million in new revenues over 10 years for local taxing entities. Tack onto that $\$ 79.3$ million that the state government would generate." (Vandenack, 2006b).

In the media, local government officials and representatives of the ethanol industry often remark on these multiple shared benefits when describing plans for establishing an ethanol plant in a community. "It's going to be a win-win situation all the way around, [Seward County] Commissioner Joyce Hibler said"' (Vandenack, 2006a). Here, much of the focus is dedicated to anticipating success stories of biofuels development in the region:

"It's a project that everybody in Seward County and Liberal can be proud of," [Conestoga Energy Partners LLC President] Hatcher concluded. I think it will be an exceptional industry to have as far as agriculture is concerned, and I believe that agriculture is probably the mainstay of our community." (Bridenstine, 2006) 
Agriculture and ethanol production are often characterized in the western Kansas media as indivisible and as the "lifeblood" of the region's economy. The economic development frame highlights the successes of the ethanol industry, the fast pace at which biorefineries are being built, and anticipated economic rewards for local investors. The building costs and the results from economic impact studies associated with each ethanol plant are often published, detailing payouts to crop producers, the number of direct jobs created, the payrolls, and the potential tax revenues for the community and county. By publishing the huge dollar amounts raised in record time for the construction of these ethanol plants, the ethanol complex is portrayed by the local media as an unstoppable growth industry. The partial tax abatements and tax increment financing offered to the ethanol industry by state and local governments are also reported and described as good policies to attract ethanol plants to communities in western Kansas.

The pervasive economic development frame employed in the analyzed newspapers is geared towards promoting high expectations for success. Potential profits for farmers and rural communities are accentuated, and the benefits of biorefineries for investors, job searchers, and regional economic growth, are highlighted. The discourse in the regional newspapers suggests that there is little excuse not to grow the ethanol industry in western Kansas, and this sentiment was repeated in many interviews. For example, one community member explained: “Maybe it isn't going to be around for 100 years. Maybe it's not the answer to everything, but it's here and it's now and it can help." (Liberal interview \#7)

Similar to the way in which the energy independence frame played out slightly differently in the local newspapers than in the national media, the economic development 
frame employed to support biofuels development in rural communities was also colored by the cultural politics of western Kansas, reflecting its particular values and interests. The discourse positioning ethanol plants as partners and "good corporate citizens" was also heard repeatedly in interviews. Many community members, local businesses, and government leaders stressed how essential the resources brought by the industry were to the everyday activities and functioning of these declining rural places, as many lacked resources for schools and other institutions:

“... and with US White Energy they were involved in the community... they made a donation to the school district and they were very pro-active and having things done and being identified with community events...and so good paying job was number one but I really feel that they were good part of the community ... they buy their parts and things locally ... so all these things come back - it's not just the job set around by the plant but the local contractors, the local part sellers also benefited by having this industry in place.” (Russell interview \#2)

In several interviews, community members expressed an intangible sense of pride because their community had an ethanol plant while the neighboring community did not. This pride also instilled a sense of hope for the future of the community. For example, one community member stated:

"I think most people are proud that Phillipsburg has an ethanol plant. I think, again, that that's a sign of being a community that's a little bit more progressive than the community next door that we may be rivals with whether it's for playing 
sports in school or they're in our league or that kind of thing." (Phillipsburg interview \#7)

\subsection{The environmental frame: 'farmers make good use of water'}

At both the national and international levels, biofuels development was initially promoted in the mid-2000s for its potential to mitigate climate change through lower greenhouse gas emissions than fossil fuels (Hill et al., 2006; Shapouri, 2004). Wright and Reid show how the environmental frame was constructed in the national media primarily to "convince readers that biofuels development could wean Americans from fossil fuel use, reduce carbon emissions, and slow global warming" (2011:1394). In Lehrer (2010), this national frame also included broader environmental conservation benefits promised by biofuels, including habitat conservation and improvements to soil and water quality. In contrast, the regional newspapers in Kansas sidelined discussions of the climate mitigation benefits of biofuels; in 2008, when the national and international media began to question climate benefits and raise food security concerns related to biofuels production, with negative environmental framings outpacing positive environmental framings, these new concerns were similarly never discussed in the local media. Instead, ethanol was lauded in the local media for its direct air quality benefit of cutting carbon monoxide emissions. Ethanol was promoted as a renewable, environmentally-friendly gasoline oxygenate, a perfect substitute for the toxic MTBE. The analyzed newspaper articles emphasize these benefits but neglect to mention other air quality problems that accompany biofuels production, such as the increased release of volatile organic compounds (VOCs) that may affect air quality in the vicinity of biorefineries (MPCA, 2007). 
During the analyzed period, only nine articles mentioned any possible negative environmental effects related to ethanol production. Importantly, these nine articles were news pieces reprinted from national sources such as the Associated Press or The New York Times. Although the regional newspapers did not publish any news articles on these topics, there were a handful of Letters to the Editor and editorials that questioned whether the environmental impacts of ethanol development would be wholly positive, and expressed concern about the likely impact on local water supplies. We first analyze these opinion pieces here to explore how salient environmental issues reflect local concerns and cultural politics, and then discuss how water issues, including aquifer overdraft and water scarcity, are naturalized in the media. In contrast to the Letters to the Editor that are critical of water use for ethanol production, the local media reframes water use by the ethanol industry as positive because of its economic development benefits. In addition, the local media highlights the water conservation efforts of the ethanol industry. Both of these framings of water use also appear in our interviews. In the section below, we illustrate how water use is discussed in western Kansas, minimizing environmental concerns related to the ethanol industry by "diversionary reframing" of these issues as non-problematic (Freudenburg, 2000; McCright and Dunlap, 2003)

Between February 2006 and July 2007, the analyzed newspapers printed eight Letters to the Editor and three Editorials that expressed concern about groundwater mining for biofuels development, including the amount of irrigation water needed to grow corn for ethanol and the quantity of water used in the ethanol refining process at the plant sites. The wisdom of growing irrigated corn for ethanol in a region where water is a scarce commodity is questioned in one of the opinion pieces: 
Promoting Ethanol in Rural Kansas: local framings and cultural politics

"It seems reasonable to grow corn for ethanol if we irrigate with river water and groundwater that can be replaced. But I question whether ethanol is a viable fuel when it requires irreplaceable groundwater."

(Miller, 2006)

Although the topics of drought and diminishing groundwater availability were present, mostly as personal opinions in Letters to the Editor, water mining is normalized as a "non-issue" (Freudenburg, 2000), even at a time of manifest scarcity. Local farmers" outrage at those who question growing corn for ethanol in the region was clear throughout the pages of the analyzed newspapers, as well as our interviews:

"I would like to say that we have been planting corn for a hundred years and the only time they decided that we shouldn't plant corn is when ethanol came out. And you know, I heard people say, "oh corn is just terrible." We've planted corn all our lives, and now they're saying it's terrible for the rainforest...I don't understand. It just...I get so angry. It's just terrible, because it's happened for a hundred years." (Garnett interview \#1)

As discussed above, the depletion of Ogallala/High Plains aquifer puts the longterm viability of agriculture in western Kansas at risk (Sanderson and Frey, 2014a; 2014b). Areas of the Ogallala/High Plains Aquifer have been shown to be nearly depleted (Opie, 2000) and research predicts that other sections will be exhausted by 2025 (Sophocleous, 2005). If agriculture in the region is to remain sustainable, Steward et al. (2013) argue that withdrawals will need to be reduced by $80 \%$ to be brought in line with the rate of natural recharge. However, aside from the critiques contained in the opinion 
pieces, overt criticism of water use in the ethanol industry was not found in the local media. Instead, water use was normalized and naturalized as essential for regional economic development and as part of the agricultural heritage of the region. Farmers and state water officials framed water use for ethanol as justifiable because it brings high returns to the rural economy. For instance, one regional rural water district manager explained that one of the main benefits of the ethanol plants in the area is "a higher value use of the water that's being consumed" (relative to irrigation for agriculture):

"... so the interest, sort of, is to use the consumption of water to build the infrastructure for higher value uses of the water and then hopefully as we talk about and maybe sometime, implement cut backs in the rates that we're consuming the water, we can still sustain a pretty strong economy with the higher value uses. ... so if you're gonna consume a bucket of water, you want to get as much benefit out of it as you can, so it's strongly perceived by the other [water] district managers, particularly, that ethanol production, ethanol plants are a good thing." (Liberal interview \#7)

The naturalization of water use for ethanol and agricultural production more generally is apparent in the way that the analyzed newspapers tend to shift discussions about water from the environmental frame to the economic development frame. Article titles such as "Farmers make good use of water" and "Water pumps up crop yields and that, in turn, is a major driver of Kansas' economy" suggest that there is no actual shortage of water, but rather simply a lack of infrastructure to make it available at the desired locations and time. Advocates of biofuels development in both the articles and 
interviews also suggest that groundwater is there for one reason: to be used by local farmers, and by extension, for the production of ethanol. This approach to water issues draws upon tradition and customs that embrace natural resource extraction and justify continued water mining as the legacy and heritage of the rural community, as Solis (2005) also showed in her analysis of the opposition to a rural-urban water transfer in Kansas. A strong defender of farmers' water rights and proponent of biofuels development in the region illustrates this framing of water availability in an opinion piece:

"So, there is rarely ever an actual shortage of water. Rather, it is a lack of feasibility or facilities to make it available at the desired location when needed. [...] Thus, there is tremendous value obtained from the water held on farm fields. We are selling it and shipping it out in trains and trucks as hay, grain, meat, cotton, ethanol and more - rather than watching it run off to the sea. This is the major basis of the Kansas economy. (The Salina Journal Letter to the Editor, 2006)

Farmers are well-informed about the diminishing groundwater supply in the region and fear that the state government's proposed sustainable water policy (Sophocleous, 2010) would lead to restrictions on water use that would cripple agriculture. Farmers in western Kansas claim ownership of the groundwater under their farms and believe that they should make as much profit as they can from it while it lasts. Their claims over water are framed as key to their economic identity and cultural heritage as an agricultural community: 
"I mean, if you're an irrigation farmer, you have to irrigate that part of your land. You can't just stop watering because then you can't make the money to pay off your debt, and so on. So, they're gonna keep pumping as long as they can sell their crops for the price that can pay for the pumping. And when will that stop?" (Liberal interview \#1)

Finally, the water conservation efforts of ethanol plants in the area are often heralded in regional media and in interviews. Community and business leaders and representatives of ethanol industry praise the ways that local ethanol plants cooperate with host communities to cut water consumption and retrofit plants in order to recycle as much water as industrial processes will allow. These water saving initiatives are often mentioned in the newspapers alongside the economic benefits created by the plants, the donations given to schools, and the ethanol plant's good neighborliness. This discourse has the effect of naturalizing water use needed for ethanol production, while valorizing water conservation by linking it to good corporate citizenship, suggesting that the former is inevitable while the latter highlights the extra efforts the refineries make for their community:

“The plant [U.S. Energy Partners in Russell] has cut back on its consumption as much as it can, said Ron Dunbar, vice president of manufacturing ethanol. 'Wherever we were using the water once, we're now using it two or three times [...] We've got it as tight as we're ever gonna get it right now, and now we're gonna have to continue working on some (research and development) to see how much farther we can take this. "’ (Manly, 2006) 
These positive descriptions of the environmental impacts of ethanol plants portrayed in the media were echoed in many of our interviews. In addition to water conservation efforts, interviewees mentioned the efforts plants made to look for additional sources of water:

"During the period of the water restrictions they (the plant) showed exceptional leadership in working with the city, working with the community - finding other sources of water... and they get as far as we did a program where they purchased low flow water showerheads and we would give them out through the city office, here."(Russell interview \#2)

Present in the ethanol discourse in western Kansas is a sense of entitlement to water resources on the part of farmers and ethanol industry, as well as an assumption that the loss of groundwater through irrigation and ethanol production in the area is inevitable. Many local stakeholders express a collective view that only energy costs could limit water pumping and that agricultural interests should "use it while it is there." This sentiment was also echoed in interviews:

"And it came down to we're mining for water and it's the same as Appalachia... And it'll just be gone and then what'll happen is probably what happened in Appalachia - a lot of people will probably leave and then a lot of people will stay and then they'll be left with less economy. And hopefully we can extend that for some years, otherwise we'll go somewhere else." (Liberal interview \#2)

The discourse employed in the regional media suggests that groundwater withdrawal will not slow down as water mining for crop irrigation is inextricably linked 
to the region's agricultural heritage and sense of place, and to the cultural politics of development:

"Even in areas where the aquifer has basically gone, the people do not want to give up their water right. So you have that mindset that sort of works against the effectiveness of incentives of permanently retiring water rights.” (Liberal interview \#7)

Framing water use as a catalyst for economic development rather than understanding regional water scarcity as a natural resource constraint with the potential to undermine community well-being enables biofuels advocates to continue to push for water access to drive industry growth. Similarly, farmers are able to draw on this discourse to make claims over water, connecting ethanol production to agricultural heritage and community identity in western Kansas, and privileging economic gain over environmental quality.

\section{Conclusion}

Through the analysis of media discourse and interviews with local stakeholders in western Kansas, we illustrate how the risks and benefits of biofuels development are framed by supporters to advocate for industry development. The fine-grained analysis allows us to illuminate the cultural politics and ideologies that shape how the biofuels industry is portrayed and promoted locally, and how this promotion resonates with local values and culture.

This article contributes to recent literature examining the discourse surrounding biofuels development by showing how the frames employed in the national media -economic development, energy independence/national security, and the environment--are employed in locally contingent ways in rural areas in Kansas. The mobilization of frames 
that appeal to locally salient and culturally meaningful issues enables the ethanol industry to gain on-the-ground support for biorefineries in the communities where they will be sited. Gaining insight into the differences between national and localized biofuels narratives is critical to understanding the social and economic processes that enable the continued development of biofuels and other resource intensive industries in rural places, despite their potential negative impacts on communities and the environment.

Drawing from the literatures examining the cultural politics in rural U.S. communities and biofuels discourses and imaginaries, we demonstrate how advocates of ethanol development in Kansas are able to connect disparate claims about the benefits of biofuels development to locally salient and culturally meaningful issues by reframing these in ways that resonate with the culture, politics, and ideologies in western Kansas. By illuminating how the cultural politics of rural Kansas enable biofuels development to gain legitimacy and support in western Kansas, this paper calls attention to the ways that discursive frames that appeal to local identities and heritage may stamp out contentious views or challenges to the assumed positive effects of the biofuels industry on rural development, environmental quality, and energy independence. This is seen in the near total absence of any discussion in the analyzed articles or interviews about the negative consequences of biofuels on water resources, as well as the defensiveness exhibited by farmers when the benefits of growing corn for ethanol are questioned.

Understanding how national biofuel narratives are appropriated and deployed locally in ways that resonate with local culture and behavior helps explain why more resistance to biofuels does not appear in communities where industries are sited (Sherman, 2006). Similar to the findings of Bell and York (2011) and Scott (2010), we show that 
Promoting Ethanol in Rural Kansas: local framings and cultural politics

promoters frame the benefits of ethanol production in terms of the concrete, material needs of declining rural communities, ignoring its detrimental impacts on water resources and limited economic development potential. Our research adds to the rural studies literature that explains how powerful discourses and ideologies can interact to advance agendas that may actually be counter to sustainable economic and environmental futures in rural communities. 
Promoting Ethanol in Rural Kansas: local framings and cultural politics

Acknowledgments: This research was supported by the United

States Department of Energy (DOE) under Grant No. DE-FG02-

07ER64476. Any opinions, findings, and conclusions expressed in

this article are those of the authors and do not necessarily reflect the views of the DOE. 


\section{References}

Altheide, D., 1996. Qualitative Media Analysis. Sage Publications, Thousand Oaks.

Bain, C., 2011. Constructing the local: an assessment of ethanol plant ownership in Iowa. Biomass and Bioenergy 35(4): 1400-1407.

Bain, C., A. Prokos, and H. Liu. 2012. Community Support of Ethanol Plants: Does Local Ownership Matter? Rural Sociology. 77(2): 143-170.

Bell, S. and York, R., 2010. Community economic identity: the coal industry and ideological construction in West Virginia. Rural Sociology 74, pp. 111-143.

Bridenstine, T., 2006, June 28. Ethanol: separating facts from fiction. Southwest Daily Times.

Brooks, N.L., Stucker, T. and Bailey, J., 1986. Income and well-being of farms and the farm financial crisis. Rural Sociology 51 (4), pp. 391-405.

Browning, D., Kennedy, T. and Serres, C., 2007, November 7. Ethanol fever fires up heartland people jumping at the chance to buy into sprouting plants. The Salina Journal.

Bultena, G., Lasley, P. and Geller, J., 1986. The farm crisis: patterns and the impacts of financial distress among Iowa farm families. Rural Sociology 51 (4), pp. 436-448.

Burke, G., 2006, February 23. Biofuel boom - Kansas Town a supply chain for alternative fuel. The Topeka Capitol Journal.

Buttel, Frederic. 1996. Environmental and Resource Sociology: Theoretical issues and Opportunities for Synthesis. Rural Sociology 61(1):56-75.

Carolan, M.S. 2009. A sociological look at biofuels: ethanol in the early decades of the twentieth century and lessons for today. Rural Sociology 74(1): 86-112.

Cloke, P. 2006. Constructing Rurality. Pp. 18-28 in Cloke, P., Marsden,T., and Mooney, P. eds. 2006. Handbook of Rural Studies. London: Sage Publications.

Creswell, J. 2013. Qualitative Inquiry and Research Design: Choosing Among Five Approaches Third Edition. Los Angeles: Sage Publications.

Dryzek, J., 2005. Politics of the Earth: Environmental Discourses. Oxford University Press, Oxford.

Dudley, K. 2002. Debt and dispossession: farm loss in America's heartland. Chicago: University of Chicago Press. 
DuPuis, E. M, Vandergeest, P (eds). 1996. Creating the Countryside: The Politics of Rural and Environmental Discourse. Philadelphia: Temple University.

Eaton, W.M., Gasteyer, S.P. and Busch, L., 2014. Bioenergy futures: framing sociotechnical imaginaries in local places. Rural Sociology 79 (2), pp. 227-256.

Entman, R.M., 1993. Framing: toward clarification of a fractured paradigm. Journal of Communication 43, pp. 51-58.

Farley, S., 2007, August 24. Energizing Hugoton. The Garden City Telegram.

Flora, C.B., Flora, J.L., Spears, J.D. and Swanson, L.E., 1992. Rural Communities: Legacy and Change. Westview Press, Boulder.

Fox, J., 1999. Mountaintop removal in West Virginia: an environmental sacrifice zone. Organization and Environment 12 (2), pp. 163-183.

Freudenburg, W.R., 1992. Addictive economies: extractive industries and vulnerable localities in a changing world economy. Rural Sociology 57 (3), 305-32.

Freudenburg, W., Frickel, S. and Gramling R.. 1995. Beyond the nature/society divide: Learning to think about a mountain. Sociological Forum 10(3): 361-392.

Freudenburg, W.R., 2000. Social constructions and social constrictions: toward analyzing the social construction of 'the naturalized' as well as 'the natural'. In: Spaargaren, G., Mol, A. and Buttel H., Editors, 2000. Environment and Global Modernity, Sage, London.

Goffman, E., 1974. Frame Analysis: An Essay on the Organization of Experience. Harper Colophon Books, New York.

Golden, B. and Peterson, J., 2006. Evaluation of water conservation from more efficient irrigation systems. Staff Paper No 06-03, Department of Agricultural Economics, Kansas State University.

Habermas, J. 1975. Legitimation Crisis. Translated by T. McCarthy. Boston, MA: Beacon.

Hajer, M. and Versteeg, W., 2005. A decade of discourse analysis of environmental politics: achievements, challenges, perspectives. Journal of Environmental Policy and Planning 7 (3), pp. 175-184.

Hall, A., 2010. Embracing dynamism: the next phase in Kansas economic development policy. Kansas, Inc., Topeka.

https://business.ku.edu/sites/businessdev.drupal.ku.edu/files/images/general/Research/KS \%20Inc--Embracing\%20Dynamism\%20(3.11.10).pdf Accessed 2/17/15 
Hill, J., Nelson, E., Tilman, D., Polasky, S. and Tiffany, D., 2006. Environmental, economic, and energetic costs and benefits of biodiesel and ethanol biofuels. Proceedings of the National Academy of Sciences 103 (30), pp. 11206-11210.

Johnson, K. and Rathge, R., 2005. Agricultural dependence, economic hardship, and population change in the Great Plains. In: Brown, D. and Kendall, W., Editors, 2005. Population Change and Rural Society: The Changing Face of Rural America, Kluwer Press, Boston.

Kansas Energy Information Network, 2013. http://kansasenergy.org/pratt-ethanol-plant/. Accessed 2/15/15.

Kessinger, S., 2006a, August 23. Moran backing renewable energy plan - Kansas congressman joins agricultural leaders in push for ' $25 \mathrm{X}$ '25. The Salina Journal.

Kessinger, S., 2006b, June 10. Governor: rural areas lack basics to prosper. The Salina Journal.

Krider, C., Hurd, G. and Hanson, D., 2006. Trends in the Kansas economy 1985 - 2006. Kansas, Inc., Topeka.

Kuletz, V.L., 1998. The Tainted Desert: Environmental and Social Ruin in the American West. Routledge, New York.

Lehrer, N., 2010. (Bio)fueling farm policy: the biofuels boom and the 2008 farm bill. Agriculture and Human Values 27, pp. 427-444.

Lobao, L.M., 1996. A sociology of periphery versus a peripheral sociology: rural sociology and the dimension of space. Rural Sociology 61, pp. 77-102.

Lyson, T.A. and Falk, W.W., 1993. Forgotten Places: Uneven Development in Rural America. University of Kansas Press, Lawrence.

Manly, W., 2006, July 23. Russel changing water habits. The Hays Daily News.

McCracken, Resnick-Ault, and Etter. 2008. Verasun Seeks Bankruptcy Protection. Wall Street Journal. http://www.wsj.com/articles/SB122552670080390765. Accessed 2/17/15. Miller, D., 2006, August 6. When looking at future, look at water. The Hays Daily News.

Minnesota Pollution Control Agency (MPCA)., 2008. Emission factors for priority biofuels in Minnesota.

Mintert, J., Woolverton, M., Kastens, T. and Leatherman, J., 2006. Agricultural commodities future: assess competitive threats to the Kansas Economy. Kansas, Inc., Topeka. 
National Research Council (NRC) of the National Academies. 2008. Water Implications of Biofuels Production in the United States. Committee on Water Implications of Biofuels Production in the United States, Water Science and Technology Board, Division on Earth and Life Studies, Washington DC: National Academies Press.

Nebraska Energy Office (NEO), 2014. Ethanol facilities capacity by state. Retrieved from: http://www.neo.ne.gov/statshtml/121/2014/121_201402.htm.

Nisbet, M.C. and Mooney, C., 2007. Framing science. Science 316 (5821), 46.

Opie, J., 2000. Ogallala: Water for a dry land. Lincoln, NE: University of Nebraska Press.

Panelli, R., 2006. Pp.63-90 in Cloke, P., Marsden,T., and Mooney, P. eds. 2006.

Handbook of Rural Studies. London: Sage Publications.

Peterson, J.M., Ding, Y. and Roe, J.D., 2003. Will the water last? Groundwater use trends and forecasts in western Kansas. Paper prepared for presentation at the 2003 Agricultural and Economics Risk and Profit Conference, Manhattan, Kansas.

Polansky, A., 2008. Agriculture and the bioeconomy. Presentation at the Kansas Wind and Renewable Energy Conference. Retrieved from: www.kcc.ks.gov/energy/kwrec_08/presentations/B1_Polansky.ppt. Accessed 8/15/14.

Sanderson, M.R. and Frey, R.S., 2014a. From desert to breadbasket...to desert again? A metabolic rift in the High Plains Aquifer. Journal of Political Ecology, 21, pp. 516-532.

Sanderson M.R. and Frey, R.S., 2014b. Structural impediments to sustainable groundwater management in the High Plains Aquifer of western Kansas. Agriculture and Human Values. Retrieved from http://download.springer.com/static/pdf/586/art\%253A10.1007\%252Fs10460-014-95676.pdf?auth66=1424275538_b2b7e7a57c72e633cfb1ad0c6df75eaa\&ext=.pdf. Accessed $2 / 18 / 2015$.

Scott, R., 2010. Removing Mountains: Extracting Nature and Identity in the Appalachian Coalfields. University of Minnesota Press, Minneapolis.

Secchi, S., P. Gassman, M. Jha, L. Kurkalova, and C. Kling. 2011b. Potential water quality changes due to corn expansion in the Upper Mississippi River Basin. Ecological Applications 21(4):1068-1084.

Sengers, F., Raven, R. and Van Venrooij, A., 2010. From riches to rags: biofuels, media discourses, and resistance to sustainable energy technologies. Energy Policy 38 (9), pp. 5013-5027. 
Sherard, J., 2005, December 1. U.S. Energy donates to schools - funds will be used for softward, fuel, and the fine arts. The Hays Daily News.

Sherman, J. 2006. Coping with Rural Poverty: Economic Survival and Moral Capital in Rural America. Social Forces 85(2): 891-913.

Sherman, J., 2009. Those Who Work, Those Who Don't: Poverty, Morality, and Family in Rural America. University of Minnesota Press, Minneapolis.

Sherow, J.E., 1990. Watering the Valley. University Press of Kansas, Lawrence.

Shapouri, H., Duffield, J. and Wang, M., 2002. The energy balance of corn ethanol. Agricultural Economic Report No. 813. U.S. Department of Agriculture.

Skjølsvold, T. M., 2012. Curb your enthusiasm: on media communication of bioenergy and the role of the news media in technology diffusion. Environmental Communication: A Journal of Nature and Culture 6 (4), pp. 512-531.

Solis, P., 2005. Water as rural heritage: reworking modernity through resource conflict in Edwards County, Kansas. Journal of Rural Studies 21, pp. 55-56.

Sophocleous, M., 2005. Groundwater recharge and sustainability in the High Plains Aquifer in Kansas, USA. Hydrogeology Journal 13 (2), pp. 351-365.

Sophocleous, M., 2010. Review: groundwater management practices, challenges, and innovations in the High Plains Aquifer, USA - lesson and recommended actions. Hydrogeology Journal 18, pp. 55-66.

Staatz, A., 2007, January 11. Biofuel growth a corner of plan. The Topeka Capitol Journal.

Steward, David R., Paul J. Brussa, Xiaoying Yang, Scott A. Staggenborg, Stephen M. Welch, and Michael D. Apley. 2013. Tapping unsustainable groundwater stores for agricultural production in the High Plains Aquifer of Kansas, projections to 2110. PNAS 110 (37).

Stull, D. and Broadway, M., 2004. Slaughterhouse Blues: The Meat and Poultry Industry in North America. Wadsworth, Belmont.

Tankard, J., 2003. The empirical approach to the study of media framing. In: Reese, S., Gandy, O. and Grant, A., Editors, 2003. Framing Public Life: Perspectives on Media and Our Understanding of the Social World. Lawrence Erlbaum Associates, New Jersey.

The Salina Journal Letter to the Editor. 2006, October 15. Water pumps up crop yields and that, in turn, is a major driver of Kansas' economy. The Salina Journal.

US Census. 2010. Kansas Quick Facts from the US Census Bureau. http://quickfacts.census.gov/qfd/states/20000.html. Accessed 2/17/15. 
USDA NASS. Various years.

http://www.nass.usda.gov/Statistics_by_State/Kansas/Publications/Annual_Statistical_Bu lletin/ff2010.pdf, Accessed 11/21/14

Vandenack, T., 2006a, July 6. Building of ethanol plants could start this month. The Hutchinson News.

Vandenack, T., 2006b, November 30. Studies: cities will benefit. The Hutchinson News.

Wilson, L., 2006, May 25. Ceremony marks beginning for plant. The Garden City Telegram.

Wright, W. and Reid, T., 2011. Green dreams or pipe dreams? Media framing of the U.S. biofuels movement. Biomass and Bioenergy 35 (4), pp. 1390-1399. 